Article

\title{
An Investigation of the Feasibility of the Organic Municipal Solid Waste Processing by Coking
}

\author{
Alexey Paukov ${ }^{1}$, Romen Magaril ${ }^{1}$ and Elena Magaril ${ }^{2, *}$ (1) \\ 1 Department of Oil and Gas Processing, Tyumen Industrial University, Volodarskogo str., 38, 625000 Tyumen, \\ Russia; paukov_an@mail.ru (A.P.); magaril7@yandex.ru (R.M.) \\ 2 Department of Environmental Economics, Ural Federal University, Mira str., 19, 620002 Ekaterinburg, Russia \\ * Correspondence: magaril67@mail.ru
}

Received: 10 November 2018; Accepted: 9 January 2019; Published: 14 January 2019

check for updates

\begin{abstract}
In the context of transition to a circular economy, one of the strategic priorities is the development of technological innovations aimed at waste processing. In this study, the foundations have been developed for a low-temperature, environmentally safe method for efficient processing of organic municipal solid waste, which may be further applied for processing both municipal and industrial waste organics in order to obtain liquid products. The maximum yield of liquid products is ensured when conducting the coking of a mixture of organic waste with long residuum in the temperature range of $400-420^{\circ} \mathrm{C}$, with a heating rate of $5-70^{\circ} \mathrm{C} / \mathrm{min}$, and with an optimal heating time to the coking temperature of $80 \mathrm{~min}$. Recommendations on the use of the waste recycling products are given. The proposed process is consistent with the principles of circular economy and does not require external energy costs because the energy needed for the process is generated by burning the gas produced during the waste coking. The process does not produce emissions into the environment and, in combination with standard refining processes, can be used to obtain commercial petroleum products.
\end{abstract}

Keywords: circular economy; organic municipal solid waste processing; coking process; processed products

\section{Introduction}

Consumption of material resources of the planet has grown three times over the past four decades [1], which exacerbates environmental challenges and requires a change in the economic development paradigm. Waste processing for obtaining useful products or energy is one of the priorities of circular economies based on «3R»-Reduce, Reuse, and Recycle [2]. In this context, technological solutions aimed at waste utilization play a strategic role in reducing environmental pressure.

Municipal solid waste (MSW), the amount of which has increased significantly over the past decades, includes food waste, paper, plastics, wood, glass, leather, rubber, textile, yard trimmings, and others materials [3]. Processing of solid waste can be carried out by biological and thermal methods. Biological methods (in particular, using aerobic technology based on oxidation by means of special microorganisms, and anaerobic digestion) are used for the processing of food, plant, and paper waste [4-10]. Aerobic composting output is used as a soil improver. Anaerobic digestion, in addition to fertilizers, produces biogas (mainly methane and carbon dioxide) and can be used as a source of renewable energy. The environmental biotechnologies such as cultivation of vermiculture, i.e., specially cultivated California worms, on waste cellulosic components [11], for obtaining a valuable concentrated organic fertilizer-biohumus—are widely spread and adopted for industrial application. 
Thermal methods of waste processing include incineration, torrefaction, pyrolysis, gasification [8,12]. The disadvantage of thermal waste processing methods is their high costs. These methods do not provide environmental safety of the process, and the products obtained are not suitable for use without additional quality improvement with the help of expensive processes. For instance, to increase the thermal efficiency of energy production from moisture-containing waste by pyrolysis and gasification, preliminary drying of raw materials is required, which increases operating costs. In thermal processing of waste, secondary slags are formed that require further utilization or disposal. The exhaust gases contain toxic compounds and require neutralization. Environmental impact caused by the processes of generating energy from waste was analyzed in review [13]. The points among all are local impacts from wood combustion and processes of the solid recovered fuel generation, also it should be noted that the innovative technologies applied to thermochemical processes at the waste-to-energy plants do not give absolute advantages in preventing environmental pollution.

Processing of MSW is considered also as an opportunity to produce motor fuels, olefins and aromatic compounds [14,15]. In view of the fact that municipal solid waste can also contain non-combustible substances, there is a problem with the necessity of an expensive pre-treatment stage [16].

There are a number of studies on thermal and catalytic decomposition of plastic waste [17-22]. The quality of plastic waste products derived through pyrolysis depends on the composition of the raw materials, and the effect of catalysts $[19,23]$. Joint catalytic processing of plastic waste and heavy oil residues is considered as a possible way to obtain fuel oil [24]. Cai et al. [25] offer alternative technologies for processing plastic waste using the coking process to produce coke, tar, and gas. It was found that the addition of plastic waste to mixed coal promotes optimization of gas composition and raises the thermal value of coking gas. The review [26] systematizes approaches to the pyrolysis processing of various types of plastics; the process parameters (reactor type, catalysts, pyrolysis temperature and its residence time, pressure, type of fluidizing gas, and its flow rate), as well as the methods of its optimization are discussed. Predicting the inclusion of plastics pyrolysis programs in the waste management plans of many countries, the authors nevertheless emphasize the need to solve many problems for obtaining liquid fuels of adequate quality, including the search for optimal catalysts. The possibilities of processing plastic waste into liquid fuels by the methods of thermal, catalytic, microwave-assisted pyrolysis, liquid-phase catalytic cracking [27], as well as using the schemes of sequential pyrolysis and catalytic reforming of plastic waste [28] have been considered. However, the resulting liquid products require significant quality improvements for commercial use. Recently, considerable attention has been drawn to microwave-assisted pyrolysis [29-31], although the technology needs further development.

In a number of waste management scenarios, the wastes are not sorted (which is typical, e.g., for Russia), so it is necessary to consider the possibility of joint processing of various types of waste. Joint catalytic pyrolysis of paper and plastic waste creates a synergistic effect on the yield of liquid products [32]. Joint pyrolysis of plastic waste with other materials (including petroleum residue) increases the yield of liquid products and reduces their viscosity [33]. Research results [24,32,33] demonstrate the possible benefits of the joint thermal processing of various types of waste with oil residues to produce fuels from waste.

Waste tires contribute significantly to the global solid waste flow [34], which calls attention to the problem of their utilization. Today, waste tires are considered potentially effective raw materials. There is growing interest in pyrolysis as a technology for processing waste tires to produce valuable petroleum products, using different types of reactors [35]. The composition, characteristics of liquid pyrolysis products of waste tires, the possibility of their use as fuels and chemical reagents, as well as the processing conditions (heating rate, temperature, etc.) are discussed in the context of the process improvement [36-38]. A number of studies are devoted to the possibility of using a mixture of tire pyrolysis oils with diesel fuel in place of conventional diesel fuel [39-43]; an improvement in the 
quality of such fuel, including environmental characteristics, is required, which is costly. The possibility of separating liquid products of catalytic pyrolysis of tires into light and heavy fractions similar to gasoline and diesel fuel with their subsequent use instead of oil fuels is considered [44], without detailed discussion of the opportunities of wide-scale practical implementation.

The technology of the gasification of MSW with production of fuel or synthesis gas is based on the incomplete combustion with oxygen deficiency and associated with the problem of contamination of waste gases with particulate matters, nitrogen oxides, hydrogen chloride, dioxins, the purification of which requires additional expenditure and exceeds the cost of synthesis gas. In addition, in the process of gasification, there is a serious problem with the formation of tar, a complex mixture of condensed high-molecular hydrocarbons which can cause corrosion and fouling. At present, the use of gasification technology is rather limited in view of the fact that it has not been sufficiently developed [45].

Food, plastic, wood waste and waste tires can be used as raw materials for torrefaction-mild and slow low-temperature pyrolysis $\left(200-350{ }^{\circ} \mathrm{C}\right)$ [46]. The main target product of the process is the char, yield of which decreases with increasing the process temperature. Heavy metals such as $\mathrm{Pb}$ and Zn may accumulate in char [9].

Recently the hydrothermal processing has been considered a promising technology for the processing of high moisture content bio-wastes to energy. Hydrothermal carbonization (HTC) technology in the presence of subcritical water has been developed, and the possibilities of its application for waste processing have been considered [47]. Food and plastic waste, in particular, may be used as raw materials for HTC [48,49].

When choosing the technology of solid waste processing, the key problem is to meet the requirements of environmental compatibility, low energy consumption, and safety. A number of studies on the problem of MSW valorization demonstrate the problem of importance, and the urgent need to find optimal industrial solutions, including the MSW-derived fuel production. In making decisions at the government level on tax incentives for the industrial implementation of waste processing programs, an integrated account of national features of waste management and criteria of economic, environmental, and social efficiency is required [50].

The method of coking compared to pyrolysis and other thermal methods requires lower energy inputs, and, in combination with refining methods, may give higher yield of marketable liquid products-gasolines, diesel fuels, and boiler fuel [51,52]. However, on the industrial scale, the method is not applied to the MSW processing and studies of the feasibility of its industrial application are very limited.

The present work is aimed at studying the thermal decomposition of unsorted organic MSW in the process of coking, and discussing the possibilities of industrial application of the process.

\section{Materials and Methods}

Coking was carried out for a mixture of long residuum- residue of primary distillation of crude oil, and municipal solid waste in a ratio of 1:4 by weight, taken on the basis of estimated ratio of the amount of waste formed and residual, unclaimed long residuum produced. The municipal solid waste used for thermolysis, which was taken according to the statistics of waste disposal excluding waste from the mineral group (glass, metal, and ceramics), consisted of paper, plastic (polyethylene disposable bottles, medical disposable syringes) 0 rubber (automobile tires) and food waste (potato peel). To understand the effect of the coking process on various types of organic materials, the study was carried out on both individual and mixed raw materials. In addition to the mixture of each of the above mentioned samples with long residuum, a mixture of all samples taken in equal proportions was used as the raw material. The use of a mixture of domestic waste with long residuum facilitates the process due to the introduction of high-molecular polycyclic hydrocarbons into the process [51-53].

The long residuum of Surgut oil used had a relative density of $\rho_{4}^{20}=0.985$; coking ability of $12-13 \%$ by weight; the sulfur content of $2.2-2.4 \%$ by weight. 
Separately, the experiment was carried out on thermolysis of long residuum without the addition of solid waste to determine the net yield of products and make up a material balance for subsequent assessment of the effect of each type of waste on the yield of coking products.

Coking was carried out using a standard laboratory batch coking unit, shown in Figure 1.

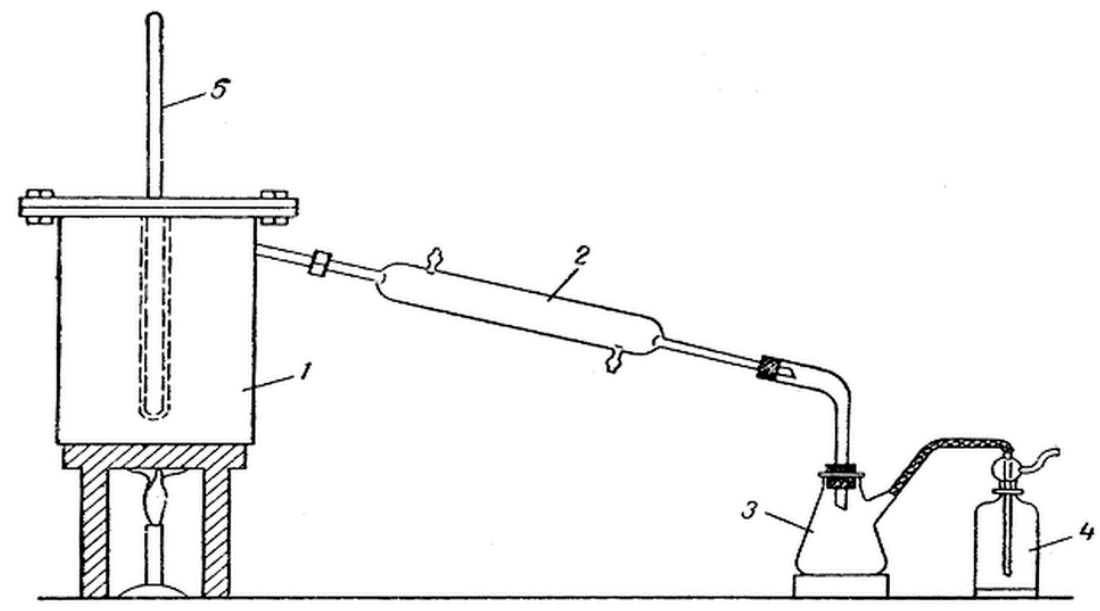

Figure 1. Laboratory batch coking unit: 1-coking reactor; 2-cooler; 3-receiver; 4-absorber; 5-thermometer.

A mixture of long residuum and waste samples was prepared for coking. The solid waste used was finely ground and mixed with long residuum; then the mixture was placed in a coking reactor at an amount of $50 \mathrm{~g}$. A water cooler, pre-weighted absorber, and receiver were subsequently attached. The reactor was heated with a gas burner.

In this study, the optimum process parameters were established by changing the heating time of raw materials to achieve the thermolysis temperature required, and by changing the thermolysis temperature at a constant heating time. The temperature range of $400-420^{\circ} \mathrm{C}$ was found to be the most favorable. In this temperature range, the maximum yield of liquid coking products was observed, and the resulting solid residue was dry and did not contain liquid high-boiling fractions. The effect of the heating rate of the raw thermolysis mixture on the yield of the thermolysis products was determined and the optimum range of the heating rate of $5-7^{\circ} \mathrm{C} / \mathrm{min}$ was established, which ensures the maximum yield of the hydrocarbon distillate. It was found that the output of coking gases and hydrocarbon distillate did not change when the raw mixture was heated up to $400{ }^{\circ} \mathrm{C}$ for more than 80 $\mathrm{min}$. Therefore, the heating time to the coking temperature should not exceed $80 \mathrm{~min}$ in order to save fuel resources.

Coking was carried out for $240 \mathrm{~min}$. After some time after heating, the temperature in the vapor increased and first drops of distillate appeared in the receiver. Then the process of decomposition and coking of the raw material was carried out at an approximately constant temperature in the range of $400-420^{\circ} \mathrm{C}$, and considerable gas release was observed. The gas was taken to a gas burette for further analysis. The end point of the coking process was determined as the end of distillate separation. After that, the reactor was heated for 30-40 $\mathrm{min}$ to calcinate the coke and remove volatile hydrocarbons. At the end of calcination, the reactor was cooled and opened.

As a result of coking, the same products such as water, hydrocarbon distillate, gas, and coke were obtained for all waste samples. At the end of each experiment, solid residue, water, distillate, and gas formed and were weighted.

After cooling, the reactor was opened and cleaned of coke. The obtained solid residue was weighted. The ash content of the solid residue was determined by the mass of ash formed after burning a sample of fuel under free access of air and calcination of the ash residue to constant weight at a temperature of $(815 \pm 10){ }^{\circ} \mathrm{C}$. The content of carbon and sulfur in the solid residue was determined by the method of IR-spectroscopy using an ELTRA CHS-580 (ELTRA GmbH) analyzer. 
The analysis of gaseous products was carried out by a gas chromatography method. Water, fractions IBP- $200{ }^{\circ} \mathrm{C}$ and $>200{ }^{\circ} \mathrm{C}$ were extracted from the coking distillate obtained. For obtained coking fractions IBP- $200{ }^{\circ} \mathrm{C}$ of each waste sample the iodine numbers were determined and $\mathrm{pH}$ was determined for the water. For each type of raw material, 3 experiments were carried out. The deviation of the composition of the products obtained from the average for different components did not exceed $5 \%$.

The scheme of the process of organic waste coking is shown in Figure 2.

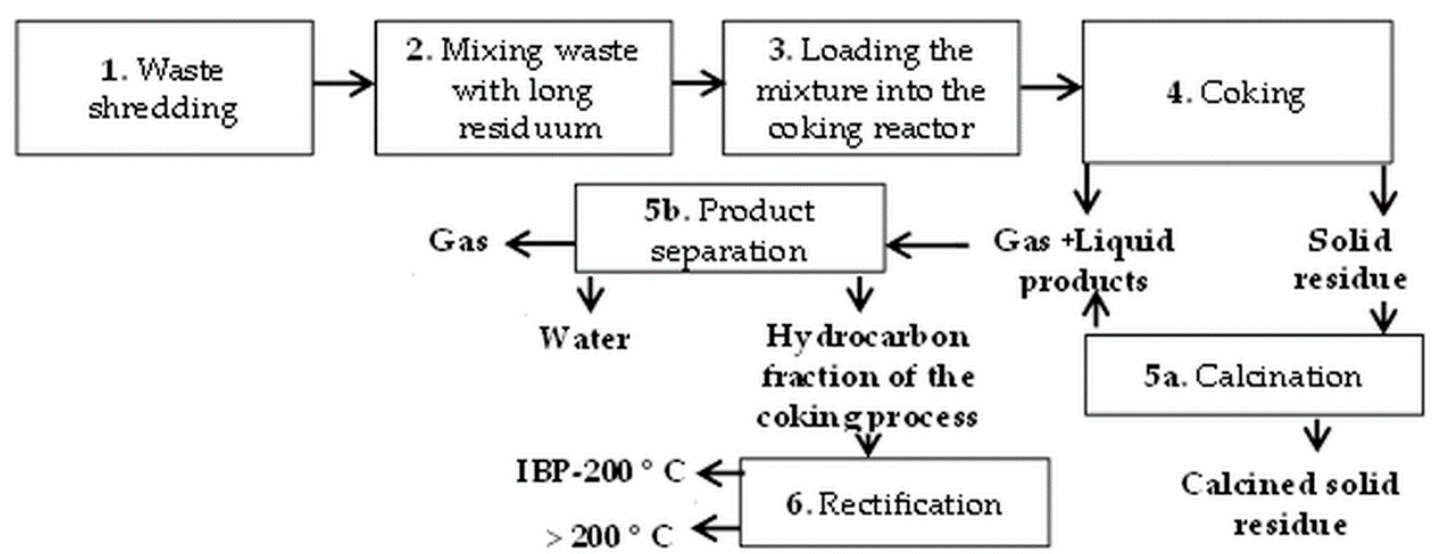

Figure 2. Technological scheme of the organic MSW coking process.

The fraction $>200{ }^{\circ} \mathrm{C}$ of coking of the mixture of municipal solid waste, taken in a ratio of 4:1 with long residuum, was used as a raw material in a laboratory unit for periodic oxidation to produce bitumen. The laboratory unit is similar to that shown in Figure 1, differing in the air supply to the bottom of the reactor. Three experiments were performed and in each of them the deviation of the yield of the products obtained (distillate, bitumen, gas + losses) from the corresponding average values did not exceed $6.5 \%$. For the distillate of the bitumen production process, the relative density, the kinematic viscosity at $20^{\circ} \mathrm{C}$, the pour point, the diesel index, and the closed-cup flash point, were determined. For the bitumen obtained, the penetration and softening point were determined.

\section{Results and Discussion}

\subsection{Coking as a Method of Municipal Solid Waste Processing}

Municipal solid waste, considered in this paper, is of organic origin. The formation of coke occurs as a result of a series of successive reactions of condensation of organic molecules, giving products with increasing molecular weight and aromatization. In general, the process of the coking of liquid raw materials can be described by the scheme proposed in [53], presented reductively in Figure 3.

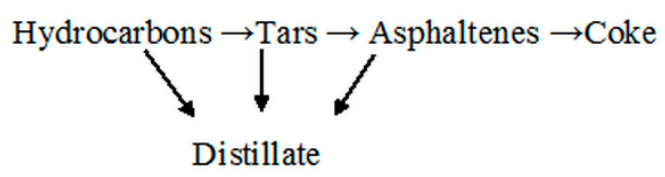

Figure 3. Scheme of the coking process of liquid organic feedstock.

The mechanism of thermal reactions is well described, for example, in [51-55]. Thermolysis of petroleum feedstock in liquid phase proceeds through the successive or parallel-sequential stages of the formation and consumption of intermediate products (oils and tars) followed by their densification to asphaltenes. In this case, all the ongoing processes are accompanied by the release of volatile hydrocarbons, which are by-products of the destruction of liquid hydrocarbons.

The coking process is a complex, multifactor, nonstationary, heterogeneous, and heterophase diffusion process with a specific hydrodynamic, mass exchange, and thermal regime. 
Thermal conversion of municipal organic waste in a mixture with petroleum residues resembles, to some extent, the process of continuous coking, where solid waste pieces are the centers of coking and, at the same time, the surface from which evaporation takes place and, as a result, densification of liquid hydrocarbons occurs.

Municipal solid waste as a constituent of the raw material for the thermolysis process is as diverse in its hydrocarbon and elemental composition as the petroleum residues. The composition of the waste that is the raw material of the thermal conversion process affects the material balance of the process.

The main parameters determining the depth of thermolysis are the temperature range of the raw mixture heating, heating rate, and time. These parameters should ensure not only primary reactions of destruction and densification, but also reactions of destruction and densification of the secondary products formed.

If the temperature is not sufficient for secondary processes of the product destruction, a gel-like mass can be obtained instead of the solid carbon residue. Overstating the coking temperature will lead to an unjustified increase in energy costs, an increase in the gaseous products yield, and a decrease in the yield of liquid coking products, which will reduce the economic efficiency of the technology being developed.

The rate of heating of the raw mixture affects the ratio of the yield of gaseous and liquid coking products. In the case of an increase in the rate of heating, newly formed products of destruction and densification will be exposed to thermal decomposition along with the main raw material, which will lead to an abundant release of gas and a reduction in the formation of liquid products of coking.

The time of heating the raw material to the temperature of coking should ensure the achievement of maximum yields of the target products. Exceeding the optimal heating time will lead to wasteful power consumption.

\subsection{Material Balance of the Organic MSW Coking Process}

Figure 4 presents the results of coking the long residuum with various samples of municipal solid waste, indicating that the selected temperature regime of the process provided its sufficient reaction depth.

The composition of the waste affected the yield of coking products. In the thermolysis of rubber, plastic bottles and medical syringes, the yield of the solid residue was much higher and gas-formation, contrary, was reduced with respect to those in the thermolysis of paper and food waste. This is due to the fact that the composition of both the rubber (car tires) and plastic waste includes concentrated polymeric hydrocarbons, which primarily affect the yield of the solid residue. In the case of the thermolysis of paper and food waste, where cellulose and vegetable fiber predominate, excessive formation of the solid residue is not possible, which is confirmed by the results given in Figure 4. In experiments with this raw material, abundant gas release was noted.

Special attention should be paid to the experiments where a mixture of MSW, long residuum, and a mixture of MSW and recycle were used as a feedstock for the thermolysis. The coking feedstock was formed using equal amounts of each waste. As a recycle, in place of long residuum, the liquid hydrocarbon fraction $>200{ }^{\circ} \mathrm{C}$ extracted from the products of thermolysis of a mixture of MSW and long residuum was used. The close values of the quantitative yield of coking products for these experiments lead us to the conclusion that at the selected ratio of solid and liquid phases, the quality of the liquid phase used does not affect the yield of thermolysis products. Earlier, in $[24,32,33]$, the synergistic effect was demonstrated in the processes of the joint thermolysis of various types of waste, including those with oil residue. At present, research results obtained show the feasibility of co-coking different types of organic waste and their mixtures with long residuum. Food waste may be included into the raw material of coking; however, their high content increases the yield of gaseous products and reduces the yield of liquid hydrocarbon fractions. 


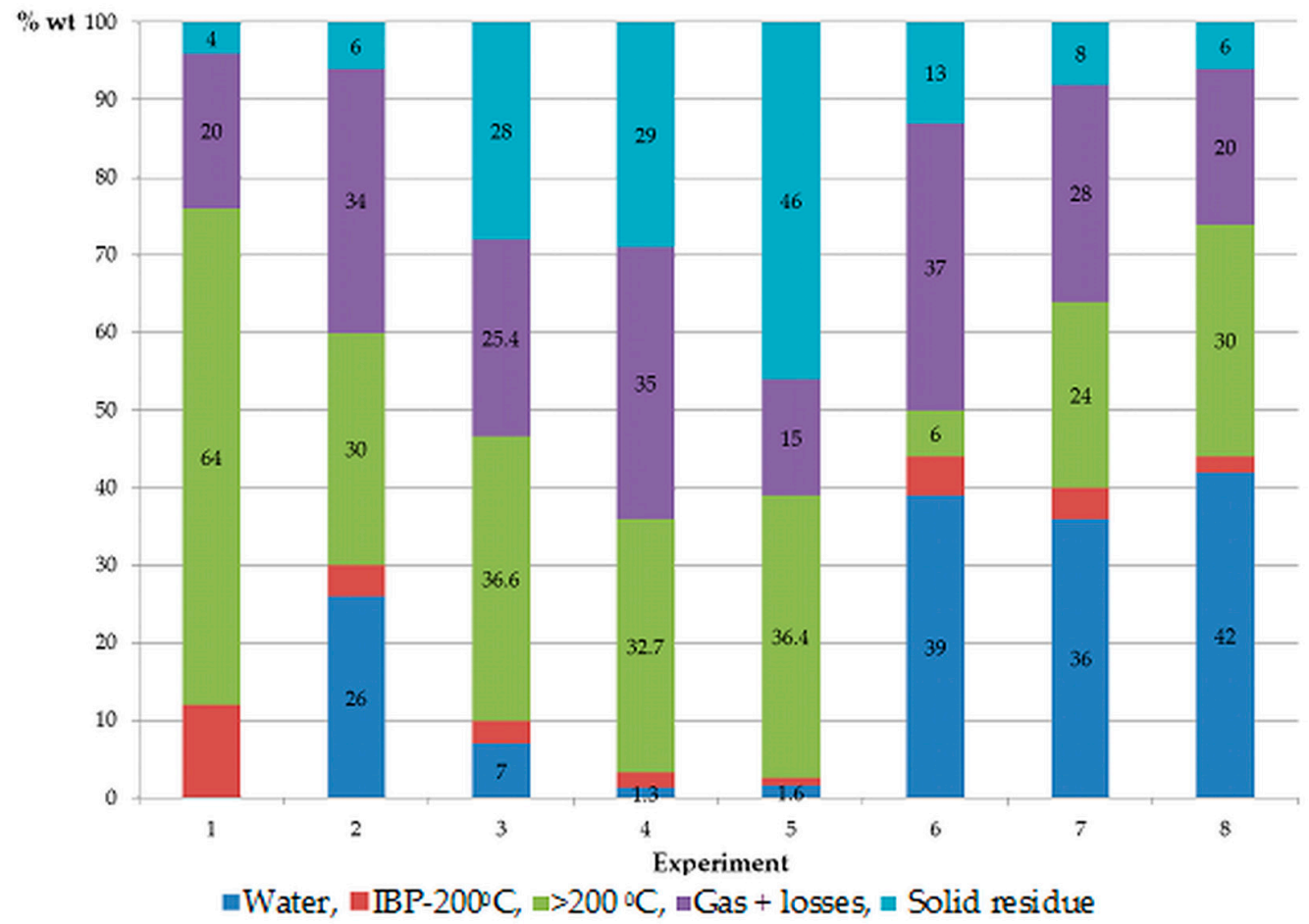

Figure 4. Material balance of the MSW coking process (raw materials of the process: 1 -long residuum; 2-7-1:4 ratio (wt): 2-long residuum + paper; 3-long residuum + rubber (car tires); 4-long residuum + plastic (bottles); 5-long residuum + plastic (syringes); 6-long residuum + food waste; 7-long residuum + MSW mixture; 8 -IBP-200 ${ }^{\circ} \mathrm{C}$ fraction from No. $7+\mathrm{MSW}$ mixture).

Water, as one of the thermolysis products, is present in all of the experiments. This is can easily be explained in the case of paper or food waste coking since water is present in the composition of these waste samples. In the case of food waste, its yield is maximum and amounts to $78 \%$ by weight on liquid thermolysis product and up to $39 \%$ by weight in general on the coking feedstock for this experiment. In the case of plastic waste and car tires, the appearance of water in the composition of thermolysis products can be explained by the destruction of macromolecular compounds that are part of the raw materials of these types of solid waste. In high-molecular compounds there are oxy- or hydroxo-groups, which form water when the processes of densification and disproportioning proceed. Thus, in the liquid-phase thermolysis of MSW, even in the absence of visible water in the coking raw materials, the products contain water. The content of oxygen-containing hydrocarbon derivatives in the feedstock affects the chemistry of the process of thermal conversion, which can be concluded from the results of the study. This does not significantly affect the technology of the coking process. The range of optimal values of temperature and time for different types of raw materials does not change.

Thus, in contrast to the results of Cai et al. [25], when such final products as coke, tar, and gas obtained in the coking process applied to the plastic waste processing, the proposed approach allowed obtaining liquid products from mixed organic waste that correspond to oil distillation fractions.

\subsection{Analysis of Products of the Liquid-Phase Thermolysis of MSW}

The coking gas, set on fire at the outlet of the reactor, ensured steady burning of a flame. The results of the analysis are given in Figure 5.

Distillate coking is a visually opaque liquid of dark color. Table 1 shows the obtained $\mathrm{pH}$ values for water and the iodine number of the IBP- $200{ }^{\circ} \mathrm{C}$ hydrocarbon fraction. Low $\mathrm{pH}$ values indicate the formation of low molecular weight water-soluble acids during the coking process, which will require alkalization of water for its use for technological needs. 


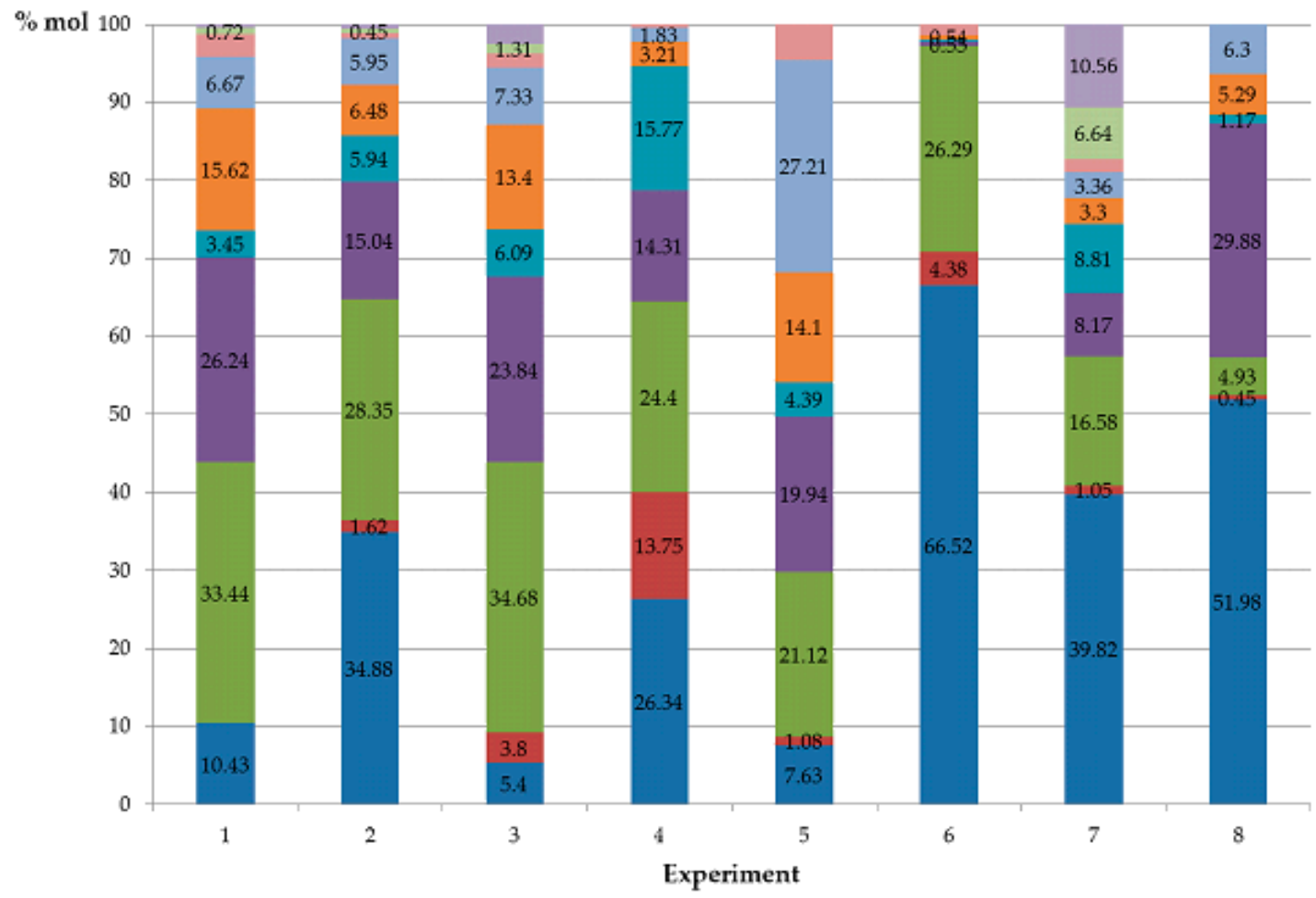

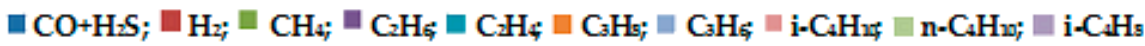

Figure 5. Composition of gaseous products of thermolysis of municipal waste (raw materials of the process: 1 -long residuum; $2-7-1: 4$ ratio (wt): 2 -long residuum + paper; 3 -long residuum + rubber (car tires); 4-long residuum + plastic (bottles); 5-long residuum + plastic (syringes); 6-long residuum + food waste; 7 -long residuum + MSW mixture; 8 - IBP-200 ${ }^{\circ} \mathrm{C}$ fraction from No. $7+$ MSW mixture).

Table 1. Results of the analysis of the municipal waste thermolysis distillate.

\begin{tabular}{|c|c|c|c|c|c|c|}
\hline \multirow{2}{*}{ 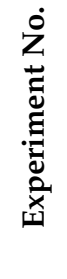 } & \multirow{2}{*}{\multicolumn{2}{|c|}{$\begin{array}{c}\text { Raw Materials of the Process, Ratio Long } \\
\text { Residuum: MSW } \\
1: 4(w t)\end{array}$}} & \multicolumn{2}{|c|}{ IBP-200 ${ }^{\circ} \mathrm{C}$} & \multicolumn{2}{|c|}{ Water } \\
\hline & & & $\begin{array}{l}\text { \% wt on } \\
\text { Raw } \\
\text { Material }\end{array}$ & $\begin{array}{c}\text { Iodine } \\
\text { Number, \%. }\end{array}$ & $\begin{array}{l}\text { \% wt on } \\
\text { Raw } \\
\text { Material }\end{array}$ & $\mathrm{pH}$ \\
\hline 1 & Long resi & um & 12.0 & 15.6 & - & - \\
\hline 2 & Long residuum & Paper & 4.0 & 17.1 & 12.0 & $2-3$ \\
\hline 3 & Long residuum & Rubber & 3.0 & 29.0 & 7.0 & $2-3$ \\
\hline 4 & Long residuum & Plastic (bottles) & 2.0 & 4.7 & 1.3 & $2-3$ \\
\hline 5 & Long residuum & Plastic (syringes) & 1.0 & 9.9 & 1.6 & $2-3$ \\
\hline 6 & Long residuum & Food waste & 5.0 & 4.6 & 39.0 & $2-3$ \\
\hline 7 & Long residuum & MSW mixture & 4.0 & 20.5 & 36.0 & 2 \\
\hline 8 & $\begin{array}{l}\text { Fraction IBP- } 200{ }^{\circ} \mathrm{C} \\
\text { from experiment No. } 7\end{array}$ & MSW mixture & 2.0 & 16.1 & 42.0 & 1 \\
\hline
\end{tabular}

For the fraction obtained by coking the paper, the hydrocarbon type content was determined, $\%$ wt: aromatic hydrocarbons-35.7, naphthenes-15.5, paraffins-48.9.

The solid residue, a dark, brittle and loose substance, contained 93-95 wt. \% of carbon, $0.44-0.72$ wt. \% of sulphur, the ash content was $0.2-0.3 \mathrm{wt}$. \%. The solid residue ensured steady smokeless burning when set on fire. 
Thus, during the thermolysis of any sample of solid waste and their mixtures, the composition of the products includes a liquid hydrocarbon distillate, water, a solid carbon residue, and a hydrocarbon gas.

As a result of the experiment on obtaining bitumen from the fraction with boiling range above $200{ }^{\circ} \mathrm{C}$, the products such as bitumen, a hydrocarbon distillate, and gas were obtained by thermolysis of the MSW mixture, taken in the ratio of 4:1 with long residuum. The material balance of the process is presented in Table 2. Table 3 shows the results of determining the quality of the distillate obtained.

Table 2. Material balance of the process of bitumen obtaining from the fraction $>200{ }^{\circ} \mathrm{C}$ of thermolysis of the mixture of municipal waste with long residuum (ratio 4:1).

\begin{tabular}{ccc}
\hline Balance Sheet Items & $\begin{array}{c}\text { On raw Materials of the Coking } \\
\text { Process, wt. \% }\end{array}$ & $\begin{array}{c}\text { On raw Materials of the Bitumen } \\
\text { Obtaining Process, wt. \% }\end{array}$ \\
\hline Raw materials & $\mathbf{2 4 . 0 0}$ & $\mathbf{1 0 0 . 0 0}$ \\
Products: & 14.60 & 60.83 \\
Distillate & 7.40 & 30.84 \\
Bitumen & 2.00 & 8.33 \\
Gas + losses & $\mathbf{2 4 . 0 0}$ & $\mathbf{1 0 0 . 0 0}$ \\
Total &
\end{tabular}

Table 3. The quality of the distillate of the process of bitumen obtaining from the fraction $>200{ }^{\circ} \mathrm{C}$ of thermolysis of the mixture of municipal waste with long residuum (ratio 4:1).

\begin{tabular}{cc}
\hline Quality Indicators & Indicator Value \\
\hline Kinematic viscosity at $20^{\circ} \mathrm{C}, \mathrm{mm}^{2} / \mathrm{s}$ & 57.57 \\
Pour point, ${ }^{\circ} \mathrm{C}$ & -18 \\
Relative density & 0.8975 \\
Diesel index & 18 \\
Flash-point temperature & 112.0 \\
\hline
\end{tabular}

Penetration of the obtained bitumen sample was $14\left(\right.$ at $25^{\circ} \mathrm{C}$, at $0.1 \mathrm{~mm}$ ); the softening point was $102^{\circ} \mathrm{C}$. The total material balance of coking of the MSW mixture is presented in Figure 6.

Based on the obtained results of the quality of thermolysis products, variants of their use can be considered. Hydrocarbon gas is particularly well suited as a fuel gas to maintain the temperature regime of the coking process. The hydrocarbon distillate without fractionation can be used first of all as a furnace fuel to maintain the temperature regime of the coking process. In addition, this product can be used as a raw material or component of a raw mixture in hydrorefining, catalytic cracking, and bitumen production processes. It is also possible to use this product in an amount of $1-5 \%$ as an additive to commercial diesel fuel, obtained at refineries.

Due to the low ash-content in the solid residue, taking into account that carbon content in it is 93-95\%, it is advisable to use it as a solid fuel.

Water, after its separation from the mixture with liquid hydrocarbons via settling with following alkalization to neutralize acidic impurities, can be used as technical water.

For the practical implementation of the proposed approach, a well-known delayed coking technology with a known energy balance can be used, which has been applied in many refineries to produce coke $[54,55]$, but hasn't been used to process organic waste yet. The process technology, for the realization of which no external energy supply is needed, when using different raw materials whose composition changes at the refinery within sufficiently wide limits, does not require changes in the processing of unsorted organic waste. Thus, for processing, unsorted organic waste has to be transported from temporary storage sites to refineries, placed in a warehouse, and then sent for processing by coking together with oil residues. 


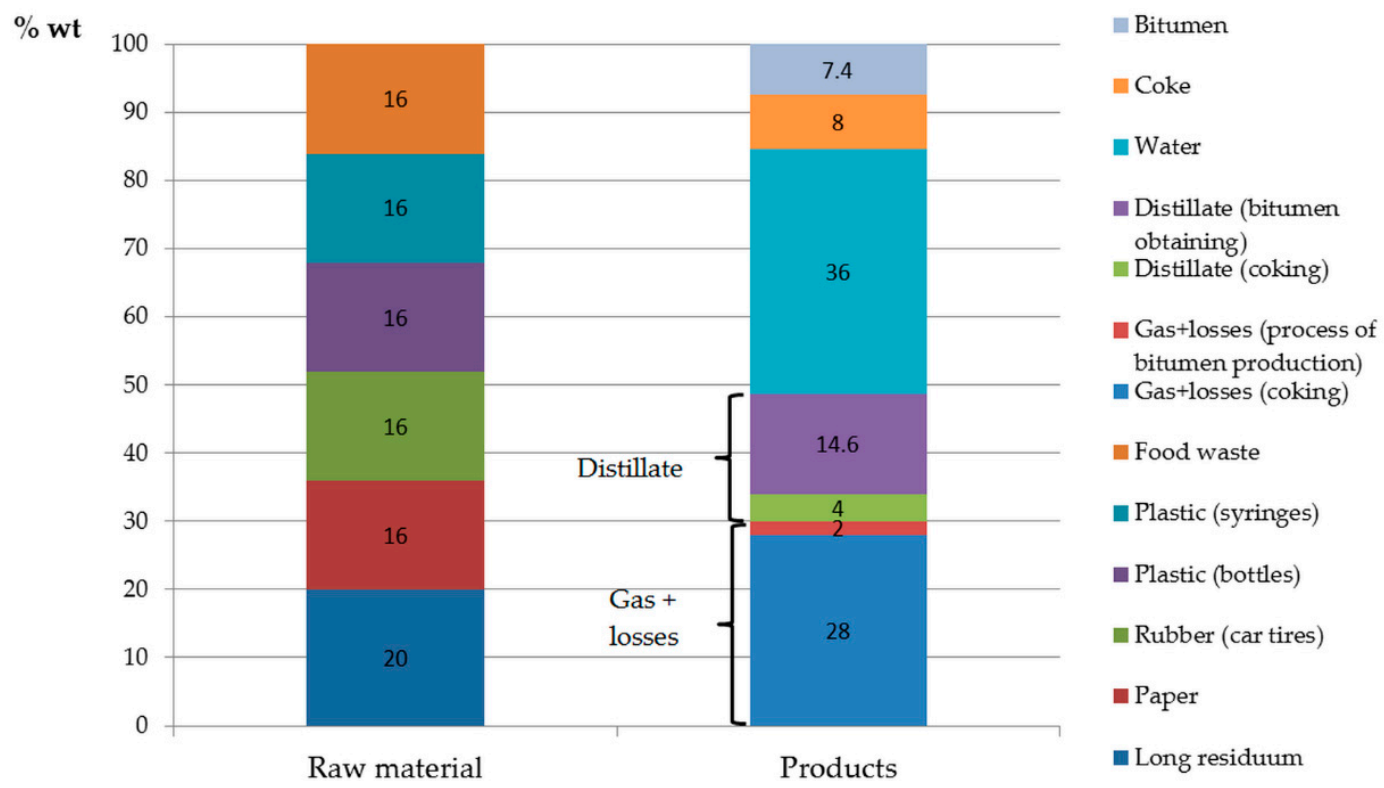

Figure 6. Total material balance of the MSW mixture processing.

\section{Conclusions}

The disadvantages of thermal-oxidative methods of waste processing are low environmental safety, complexity of technical solutions, high energy expenditure, lack of final marketable products, and high cost of the process.

The technological basics of waste processing based on the coking of the mixture of municipal solid organic waste and liquid off-grade petroleum products has been proposed. The investigations conducted allow the authors to make a conclusion on the applicability of the coking process for processing unsorted organic waste and to formulate recommendations on the use of the products obtained.

Depending on the organic waste composition, the application of the proposed approach for low-temperature organic MSW processing by coking allows obtaining 11-39.6 wt. \% of liquid fractions, which can be processed into marketable petroleum products, with release of $15-37 \mathrm{wt}$. \% of the gas, which is mainly used for energy needs in the process of coking, 6-46 wt. \% of the solid fuel in the calculation relative to the raw material of the process of coking, and $1.3-42 \mathrm{wt}$. $\%$ of water, which, after alkalization, can also be used in the technological process. The process is carried out without external energy consumption and emissions to the environment. The difference between the proposed method and the majority of the applied methods of MSW processing with predominant yield of gaseous products, is that the products obtained correspond to the fractions of direct distillation of oil (gasoline and diesel fractions, reduced crude) and can be processed in a mixture with straight-run oil fractions using conventional refining processes, respectively, to create marketable petroleum products such as gasoline, diesel fuel, boiler fuel and, if necessary, bitumen. Therefore, it is advisable to process organic municipal waste using the proposed method in refineries. Thus, as a result, the range of petroleum fuels is maintained with significant oil savings.

Since any waste of organic composition can be used as the coking feedstock, the proposed technology can be used in the future for processing both municipal and industrial waste.

Author Contributions: All the authors contributed equally to the present work.

Funding: This research received no external funding.

Acknowledgments: The work was supported by Act 211 of the Government of the Russian Federation, contract No. 02.A03.21.0006.

Conflicts of Interest: The authors declare no conflict of interest. 


\section{References}

1. Schandl, H. Global Material Flows and Resource Productivity: Assessment Report for the UNEP International Resource Panel; UNEP: Paris, Francs, 2016; pp. 6-32.

2. Ghisellini, P.; Cialani, C.; Ulgiati, S. A review on circular economy: The expected transition to a balanced interplay of environmental and economic systems. J. Clean. Prod. 2016, 114, 11-32. [CrossRef]

3. EPA. Advancing Sustainable Materials Management: 2013 Fact Sheet. Available online: https://www.epa. gov/sites/production/files/2015-09/documents/2013_advncng_smm_fs.pdf (accessed on 20 May 2016).

4. Dong, L.; Zhenhong, Y.; Yongming, S.; Xiaoying, K.; Yu, Z. Hydrogen production characteristics of the organic fraction of municipal solid wastes by anaerobic mixed culture fermentation. Int. J. Hydrog. Energy 2009, 34, 812-820. [CrossRef]

5. Elango, D.; Pulikesi, M.; Baskaralingam, P.; Ramamurthi, V.; Sivanesan, S. Production of biogas from municipal solid waste with domestic sewage. J. Hazard. Mater. 2007, 141, 301-304. [CrossRef] [PubMed]

6. Fernández-González, J.M.; Grindlay, A.L.; Serrano-Bernardo, F.; Rodríguez-Rojas, M.I.; Zamorano, M. Economic and environmental review of Waste-to-Energy systems for municipal solid waste management in medium and small municipalities. Waste Manag. 2017, 67, 360-374. [CrossRef]

7. Kim, J.H.; Lee, J.C.; Pak, D. Feasibility of producing ethanol from food waste. Waste Manag. 2011, 31, 2121-2125. [CrossRef] [PubMed]

8. Matsakas, L.; Gao, Q.; Jansson, S.; Rova, U.; Christakopoulos, P. Green conversion of municipal solid wastes into fuels and chemicals. Electron. J. Biotechnol. 2017, 26, 69-83. [CrossRef]

9. Panepinto, D.; Zanetti, M.C.; Gitelman, L.; Kozhevnikov, M.; Magaril, E.; Magaril, R. Energy from biomass for sustainable cities. IOP Ser. Earth Environ. 2017, 72, 012021. [CrossRef]

10. Ragazzi, M.; Maniscalco, M.; Torretta, V.; Ferronato, N.; Rada, E.C. Anaerobic digestion as sustainable source of energy: A dynamic approach for improving the recovery of organic waste. Energy Procedia 2017, 119, 602-614. [CrossRef]

11. Hemalatha, B.; Meenambal, T. Vermicomposting-Eco friendly disposal method for MSW and vegetable waste along with industrial effluents. Asian J. Microbiol. Biotechnol. Environ. Sci. 2006, 8, 153-154.

12. Basu, P. Biomass Gasification, Pyrolysis and Torrefaction-Practical Design and Theory, 2nd ed.; Elsevier Inc.: Atlanta, GA, USA, 2013.

13. Rada, E.C. Environmental pollution from waste and biomass energy generation. Int. J. Energy Prod. Manag. 2017, 2, 1-7. [CrossRef]

14. Niziolek, A.M.; Onel, O.; Floudas, C.A. Municipal solid waste to liquid transportation fuels, olefins, and aromatics: Process synthesis and deterministic global optimization. Comput. Chem. Eng. 2017, 102, $169-187$. [CrossRef]

15. Niziolek, A.M.; Onel, O.; Hasan, F.M.; Floudas, C.A. Municipal solid waste to liquid transportation fuels-Part II: Process synthesis and global optimization strategies. Comput. Chem. Eng. 2015, 74, 184-203. [CrossRef]

16. European Commission. Final Report: Directorate General Environment, Refuse Derived Fuel, Current Practice and Perspectives (B4-3040/2000/306517/MAR/E3). Available online: http:/ / docplayer.net/10821846-European-commission-directorate-general-environment-refusederivedfuel-current-practice-and-perspectives-b4-3040-2000-306517-mar-e3-final-report.html (accessed on 10 June 2018).

17. Al-Salem, S.M.; Antelava, A.; Constantinou, A.; Manos, G.; Dutta, A. A review on thermal and catalytic pyrolysis of plastic solid waste (PSW). J. Environ. Manag. 2017, 197, 177-198. [CrossRef] [PubMed]

18. Yoshioka, T.; Grause, G.; Eger, C.; Kaminsky, W.; Okuwaki, A. Pyrolysis of poly (ethylene terephthalate) in a fluidised bed plant. Polym. Degrad. Stab. 2004, 86, 499-504. [CrossRef]

19. López, A.; de Marco, I.; Caballero, B.M.; Laresgoiti, M.F.; Adrados, A. Pyrolysis of municipal plastic wastes: Influence of raw material composition. Waste Manag. 2010, 30, 620-627. [CrossRef] [PubMed]

20. Miandad, R.; Barakat, M.A.; Aburiazaiza, A.S.; Rehan, M.; Nizami, A.S. Catalytic pyrolysis of plastic waste: A review. Process Saf. Environ. 2016, 102, 822-838. [CrossRef]

21. Serrano, D.P.; Aguado, J.; Escola, J.M.; Peral, A. Catalytic cracking of polyethylene over zeolite mordenite with enhanced textural properties. J. Anal. Appl. Pyrol. 2009, 85, 352-358. [CrossRef] 
22. Williams, P.T.; Badri, R. Hydrocarbon gases and soils from the recycling of polystyrene waste by catalytic pyrolysis. Int. J. Energy Res. 2004, 28, 31-44. [CrossRef]

23. López, A.; de Marco, I.; Caballero, B.M.; Laresgoiti, M.F.; Adrados, A.; Torres, A. Pyrolysis of municipal plastic wastes II: Influence of raw material composition under catalytic conditions. Waste Manag. 2011, 31, 1973-1983. [CrossRef]

24. Siddiqui, M.N.; Redhwi, H.H. Catalytic coprocessing of waste plastics and petroleum residue into liquid fuel oils. J. Anal. Appl. Pyrol. 2009, 86, 141-147. [CrossRef]

25. Cai, J.-J.; Yu, G.-W.; Liao, H.-Q.; Qian, K.; Zhao, P.; He, Y.-B. Disposal of waste plastics with traditional coking process. J. Iron Steel Res. Int. 2006, 13, 5-9. [CrossRef]

26. Anuar Sharuddin, S.D.; Abnisa, F.; Wan Daud, W.M.A.; Aroua, M.K. A review on pyrolysis of plastic wastes. Energy Convers. Manag. 2016, 115, 308-326. [CrossRef]

27. Wong, S.L.; Ngadi, N.; Abdullah, T.A.T.; Inuwa, I.M. Current state and future prospects of plastic waste as source of fuel: A review. Renew. Sustain. Energy Rev. 2015, 50, 1167-1180. [CrossRef]

28. Syamsiro, M.; Saptoadi, H.; Norsujianto, T.; Noviasri, P.; Cheng, S.; Alimuddin, Z.; Yoshikawa, K. Fuel oil production from municipal plastic wastes in sequential pyrolysis and catalytic reforming reactors. Energy Procedia. 2014, 47, 180-188. [CrossRef]

29. Hussain, Z.; Khan, K.M.; Perveen, S.; Hussain, K.; Voelter, W. The conversion of waste polystyrene into useful hydrocarbons by microwave-metal interaction pyrolysis. Fuel Process. Technol. 2012, 94, 145-150. [CrossRef]

30. Ludlow-Palafox, C.; Chase, H.A. Microwave-induced pyrolysis of plastic wastes. Ind. Eng. Chem. Res. 2001, 40, 4749-4756. [CrossRef]

31. Motasemi, F.; Afzal, M.T. A review on the microwave-assisted pyrolysis technique. Renew. Sustain. Energy Rev. 2013, 28, 317-330. [CrossRef]

32. Chattopadhyay, J.; Pathak, T.S.; Srivastava, R.; Singh, A.C. Catalytic co-pyrolysis of paper biomass and plastic mixtures (HDPE (high density polyethylene), PP (polypropylene) and PET (polyethylene terephthalate)) and product analysis. Energy 2016, 103, 513-521. [CrossRef]

33. Kunwar, B.; Cheng, H.N.; Chandrashekaran, S.R.; Sharma, B.K. Plastics to fuel: A review. Renew. Sustain. Energy Rev. 2016, 54, 421-428. [CrossRef]

34. ETRMA. End of Life Tyres: A Valuable Resource with Growing Potential; European Tyre and Rubber Manufacturers Association: Saint-Josse-ten-Noode, Belgium, 2011.

35. Williams, P.T. Pyrolysis of waste tyres: A review. Waste Manag. 2013, 33, 1714-1728. [CrossRef] [PubMed]

36. Kumaravel, S.T.; Murugesan, A.; Kumaravel, A. Tyre pyrolysis oil as an alternative fuel for diesel enginesA review. Renew. Sustain. Energy Rev. 2016, 60, 1678-1685. [CrossRef]

37. Martínez, J.D.; Puy, N.; Murillo, R.; García, T.; Navarro, M.V.; Mastral, A.M. Waste tyre pyrolysis-A review. Renew. Sustain. Energy Rev. 2013, 23, 179-213. [CrossRef]

38. Quek, A.; Balasubramanian, R. Liquefaction of waste tires by pyrolysis for oil and chemicals-A review. J. Anal. Appl. Pyrol. 2013, 101, 1-16. [CrossRef]

39. Cunliffe, A.M.; Williams, P.T. Composition of oils derived from the batch pyrolysis of tyres. J. Anal. Appl. Pyrol. 1998, 44, 131-152. [CrossRef]

40. Murugan, S.; Ramaswamy, M.C.; Nagarajan, G. The use of tyre pyrolysis oil in diesel engines. Waste Manag. 2008, 28, 2743-2749. [CrossRef]

41. Murugan, S.; Ramaswamy, M.C.; Nagarajan, G. A comparative study on the performance, emission and combustion studies of a DI diesel engine using distilled tyre pyrolysis oil-diesel blends. Fuel 2008, 87, 2111-2121. [CrossRef]

42. Murugan, S.; Ramaswamy, M.C.; Nagarajan, G. Performance, emission and combustion studies of a DI diesel engine using distilled tyre pyrolysis oil-diesel blends. Fuel Process. Technol. 2008, 89, 152-159. [CrossRef]

43. Wang, W.-C.; Bai, C.-J.; Lin, C.-T.; Prakash, S. Alternative fuel produced from thermal pyrolysis of waste tires and its use in a DI diesel engine. Appl. Therm. Eng. 2016, 93, 330-338. [CrossRef]

44. Ayanoğlu, A.; Yumrutaş, R. Production of gasoline and diesel like fuels from waste tire oil by using catalytic pyrolysis. Energy 2016, 103, 456-468. [CrossRef]

45. Arena, U. Process and technological aspects of municipal solid waste gasification. A review. Waste Manag. 2012, 32, 625-639. [CrossRef] 
46. Nordin, A.; Pommer, L.; Nordwaeger, M.; Olofsson, I. Biomass conversion through torrefaction. In emphTechnologies for Converting Biomass to Useful Energy; Dahlquist, E., Ed.; CRC Press: New York, NY, USA, 2013; pp. 217-244. [CrossRef]

47. Zhao, P.; Shen, Y.; Ge, S.; Chen, Z.; Yoshikawa, K. Clean solid biofuel production from high moisture content waste biomass employing hydrothermal treatment. Appl. Energy. 2014, 131, 345-367. [CrossRef]

48. Berge, N.D.; Ro, K.S.; Mao, J.; Flora, J.R.V.; Chappell, M.A.; Bae, S. Hydrothermal carbonization of municipal waste streams. Environ. Sci. Technol. 2011, 45, 5696-5703. [CrossRef] [PubMed]

49. Lin, Y.; Ma, X.; Peng, X.; Yu, Z.; Fang, S.; Fan, Y. Combustion, pyrolysis and char $\mathrm{CO}_{2}$-gasification characteristics of hydrothermal carbonization solid fuel from municipal solid wastes. Fuel 2016, 181, 905-915. [CrossRef]

50. Alzate-Arias, S.; Jaramillo-Duque, Á.; Villada, F.; Restrepo-Cuestas, B. Assessment of government incentives for energy from waste in Colombia. Sustainability 2018, 10, 1294. [CrossRef]

51. Magaril, R.Z. Theoretical Foundations of Chemical Refining Processes; KDU: Moscow, Russia, 2010.

52. Korzun, N.V.; Magaril, R.Z. Thermal Processes of Oil Refining; KDU: Moscow, Russia, 2008.

53. Magaril, R.Z. Mechanism and Kinetics of Homogeneous Thermochemical Transformations of Hydrocarbons; Khimiya: Moscow, Russia, 1976.

54. Akhmetov, S.A. Технология глубокой переработки нефти и газа. In Advanced Oil and Gas Refining Technology; Gilem: Ufa, Russia, 2002.

55. Akhmetov, S.A.; Ishmiyarov, M.H.; Kaupfman, A.A. Oil, Gas and Solid Fuels Refining Technology; Nedra: St-Petersburg, Russia, 2009.

(C) 2019 by the authors. Licensee MDPI, Basel, Switzerland. This article is an open access article distributed under the terms and conditions of the Creative Commons Attribution (CC BY) license (http:/ / creativecommons.org/licenses/by/4.0/). 